\title{
Recent advances in geology and exploration in the Balkash-western Junggar region (Kazakhstan and Xinjiang, China): Report on the "International workshop on the large Balkash-western Junggar copper-gold province"
}

Karamay, Xinjiang, China, 22-27 August, 2011

An "International workshop on the large Balkash-western Junggar copper-gold province", supported by National 305 Project Office, International S\&T Cooperation Program of China, the National Natural Science Foundation of China, and PetrolChina Xinjiang Branch, was held in Karamay, Xinjiang Uygur Autonomous Region, from 22 to 27 August, 2011 (Fig. 1).

Eighty-two geologists from Canada, China, Germany, and Russia attended the meeting which focused on the following topics: (a) Exploration and discovery of epithermal gold deposits and porphyry copper-gold deposits; (b) Formation of the large metal province of the Balkash-western Junggar region; (c) Continental growth and related ore formation in the Junggar region; (d) Comparison of the geology and mineral resources of Xinjiang and adjacent regions. After two-days of oral presentations, some of the participants joined the 3-day conference field-trip and visited the Baiyanghe $\mathrm{Be}-\mathrm{U}$ deposit, the Baogutu Au deposit, the Baogutu porphyry $\mathrm{Cu}-\mathrm{Au}$ deposit, the DarbutSartuohay ophiolitic mélange, and the Karamay-Baijiantan ophiolitic mélange.

In general, the history of the Paleo-Asian
Ocean may be described as a series of events characterized by volcanic arcs developing from fragmentation of the continental margin of eastern Paleo-Gondwana, and accretion processes at the margin of the Siberian Craton (e.g., Zhu and Ogasawara, 2002; He et al., 2004; Windley et al., 2007). Its multi-stage geological evolution and strong continental deformations during the course of its history make the Central Asia Metallogenic Region (CAMR) a unique and complicated largescale metal province (Heinhorst et al., 2000; Kurchavov et al., 2002; Yakubuchuk, 2004). As a major part of the CAMR, the Balkash-

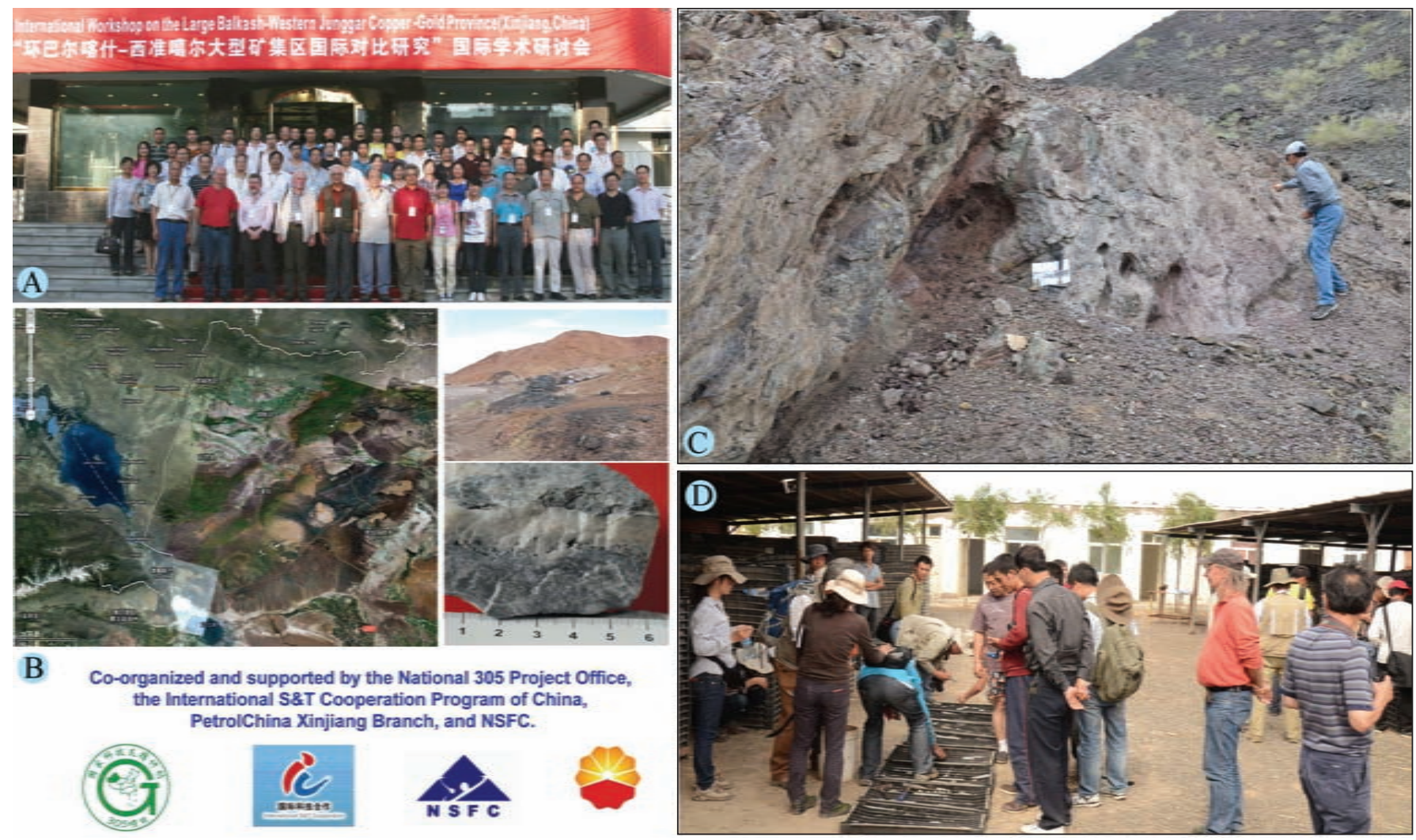

Figure 1. (A) A group photo took before the field-trip following the international workshop on the large Balkash-western Junggar coppergold province; (B) A part of the cover of the 203 page "Abstract volume with program and field-trip references" for the international workshop on the large Balkash-western Junggar copper-gold province, in which shows the location of the large Balkash-western Junggar copper-gold province, one outcrop of Baijiantan ophiolitic mélange, and one gold- and native arsenic-bearing quartz vein in the Baogutu Au mine; (C) One outcrop of ophiolitic mélange in Baijiantan, showing lenses of serpentinite, marble, gabbro in matrix; (D) Some participants are studying the drilling cores of the Baogutu porphyry copper deposit. 

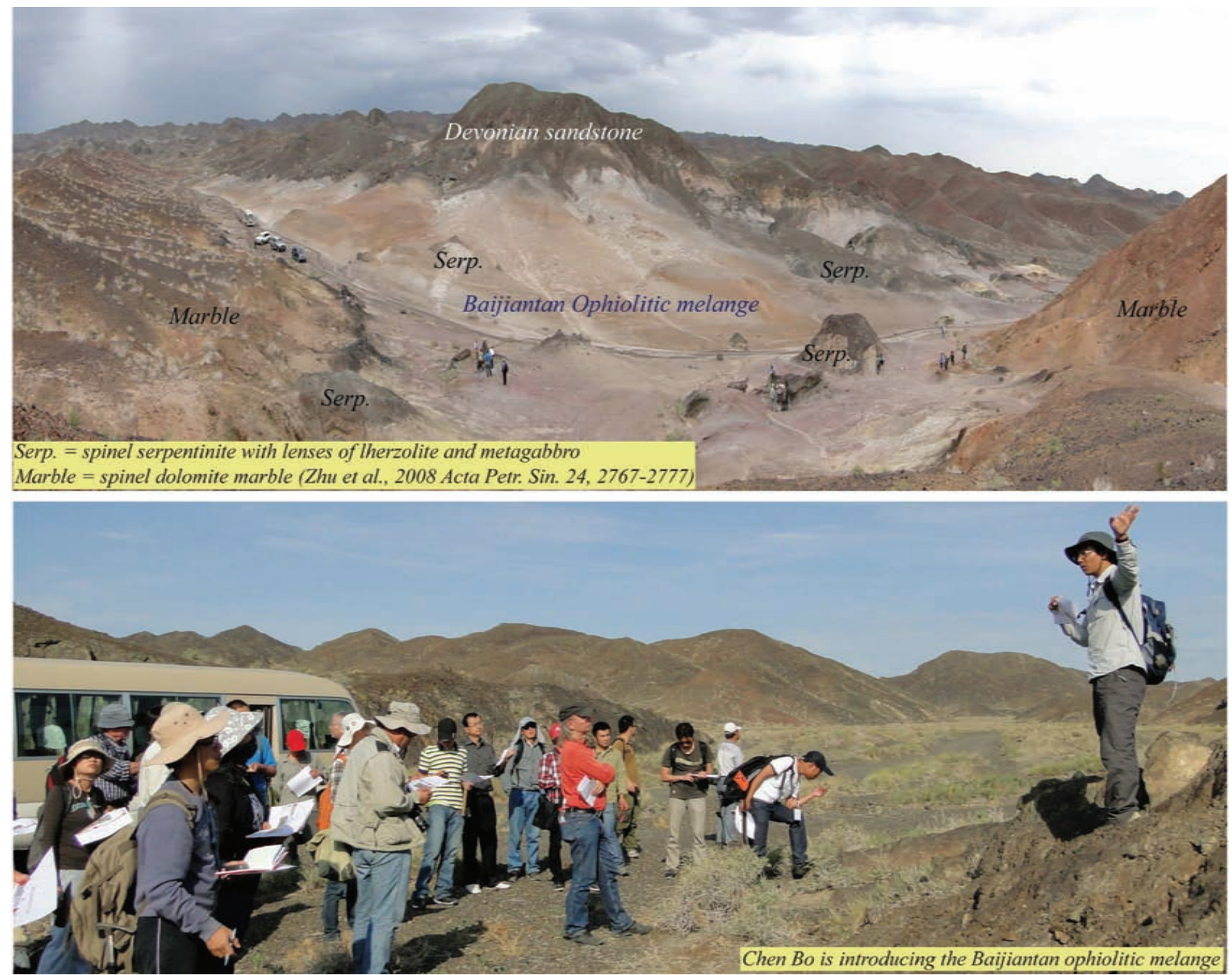

Figure 2. Top: Overview of the Baijiantan ophiolitic mélange, from SE to NW direction, with some delegates studying the outcrop. Note: Devonian sandstone overlies the ophiolitic mélange which consists of serpentinite with lenses of lherzolite, spinel dolomite marble, and metagabbro blocks (for details see Zhu et al., 2008). Bottom: Chen Bo, a PhD student from Peking University, is introducing an outcrop of the Baijiantan ophiolitic mélange to delegates joining the field-trip following the international workshop on the large Balkash-western Junggar copper-gold province.

western Junggar copper-gold province can be thought of as a natural laboratory to study the evolution of continental dynamics and related mineralization. Recently, numerous new geological observations including the discovery of Ordovician graptolites, microfossils, and unconformable contact relationships between Ordovician flysch and Devonian sandstone (see Fig. 2) and the Early Carboniferous volcano- sedimentary strata provide new data for paleogeographic and paleoenvironmental reconstruction. These and many precise isotope age data presented during the workshop allow an improved reconstruction of the geological evolution of the CAMR. It can be inferred that the western Junggar region mainly formed during closure of the Ordovician ocean. The Early-Paleozoic oceanic relics were covered by Devonian sandstone and by Early Carboniferous volcanic breccia with basaltic rocks. The latter are widespread in the western Junggar region and were previously misunderstood as arc system related to the closure of the Central Asian Paleo-Ocean. The field trip participants could observe evidence for the Devonian closure of the paleo-ocean as represented by the Karamay-Baijiantan (see Fig. 2) and Darbut-Sartuohay ophiolitic mélanges, consistent with a recently published $\mathrm{U}-\mathrm{Pb}$ age (426 Ma, Chen and Zhu, 2011) for metagabbro in the Darbut ophiolitic mélange.

During the Ordovician to Silurian, arc magmatism and relics of oceanic lithosphere were the dominant sources of continental crust accretion, resulting in the formation of the Kazakhstan-Junggar micro-plate. During the Devonian and Carboniferous, molasse formed in the western Junggar region. Postorogenic felsic magmatism, intruded into the molasse, and controlled the formation of the widespread copper-gold porphyry deposits, the Be-U deposits, and the lode gold deposits in the Balkash-western Junggar copper-gold province as well as in CAMR.

The Baogutu district, on the south-eastern side of the Darbut-Sartuohay and KaramayBaijiantan ophiolitic belts, is characterized by lode gold and copper-gold porphyry deposits. Some rare minerals including native arsenic (see Fig. 3) and native antimony in the Baogutu gold deposit have been described by An and Zhu (2009, 2010). These minerals generally co-exist with chalcopyrite, 
pyrrhotite, ullmannite, tetrahedrite, or as isolated grains enclosed in late calcite-stibnite veins.

Attention has also been given to Late Paleozoic magmatic rocks including the widespread Early Carboniferous volcanosedimentary rocks and Late Carboniferous intermediate to felsic intrusive bodies in the western Junggar region. The Early Carboniferous volcanosedimentary rocks not only host most gold and copper deposits, they also host the major part of the newly discovered hydrocarbon reservoir in the Junggar basin. Thus, progress in research on magmatic rocks in this region is not only relevant to exploration for $\mathrm{Au}$ and $\mathrm{Cu}$, but also for oil and gas.

Among the oral presentations Guoqi He (Peking University) provided an overview of the tectonic units of eastern Kazakhstan and western Junggar by showing a newly compiled tectonic map. New data as well as the Late Ordovician conodonts found in the Baijiantan ophiolitic mélange (He et al., 2007) were shown. The conodont-bearing Baijiantan ophiolitic mélange is similar to the Kujibai ophiolitic mélange in the Chinese Tarbagatai Mountains, which was dated at
478 Ma by SHRIMP on zircon from metagabbro (Zhu and Xu, 2006). Guoqi He suggested that the Karamay-Baijiantan, Darbut-Sartuohay and Kujibai ophiolitic mélanges were formed prior to Late Ordovician, similar to the ophiolitic mélanges widely distributed in eastern Kazakhstan. Yongfeng Zhu (Peking University) presented evidence for the unconformable contact between Devonian sandstone (and/or Early Carboniferous volcanic breccia with basalt) and ophiolitic mélanges both in the KaramayBaijiantan (see Fig. 2) and in the Sartohay zone. This is the first observation about such a contact in these ophiolitic belts, and thus constrains the stratigraphic position of the ophiolitic mélanges, which was misunderstood in the last decades. Both the Karamay-Baijiantan and Darbut-Sartuohay ophiolitic mélanges contain a chaotic assemblage of blocks of diverse size and rock types including strongly deformed serpentinite, meta-gabbro, chert and pillow basalt. Zircon separated from meta-gabbro in the Darbut ophiolitic mélange was dated at 426 Ma by the SHRIMP technique (Chen and Zhu, 2011). Baofu Han (Peking University) talked about the Paleozoic tectonic evolution in northwestern Xinjiang mainly based on U$\mathrm{Pb}$ ages and geochemistry of granitic rocks in this area. Jingyi Li (Chinese Academy of Geosciences, Beijing) talked about the role of large faults for the reconstruction of the ancient tectonic-metallogenic patterns in the western Junggar region.

Jeffrey Hedenquist (Ottawa, Canada) provided a thematic lecture about the transition from the tops of porphyry deposits to the base of lithocaps with several examples. He documented that recognition of the level of erosion in a lithocap setting can help to determine the distance to the base of the advanced argillic zone, and possibly the depth to the top of the causative porphyry, located typically below the muscovite-pyrophyllite transition zone. Lithocaps can be offset from the causative intrusion, whereas the pyrophyllite transition typically forms in a proximal setting. Yongjun Li (Chang'an University, Xi'an) reported the discovery of porphyry $\mathrm{Cu}-\mathrm{Mo}$ mineralization in the southern Darbut belt and the mineral exploration clues in the western Junggar region. Zhaohua Luo (Chinese University of Geosciences, Beijing) discussed the relations between the widespread pedigree dykes and

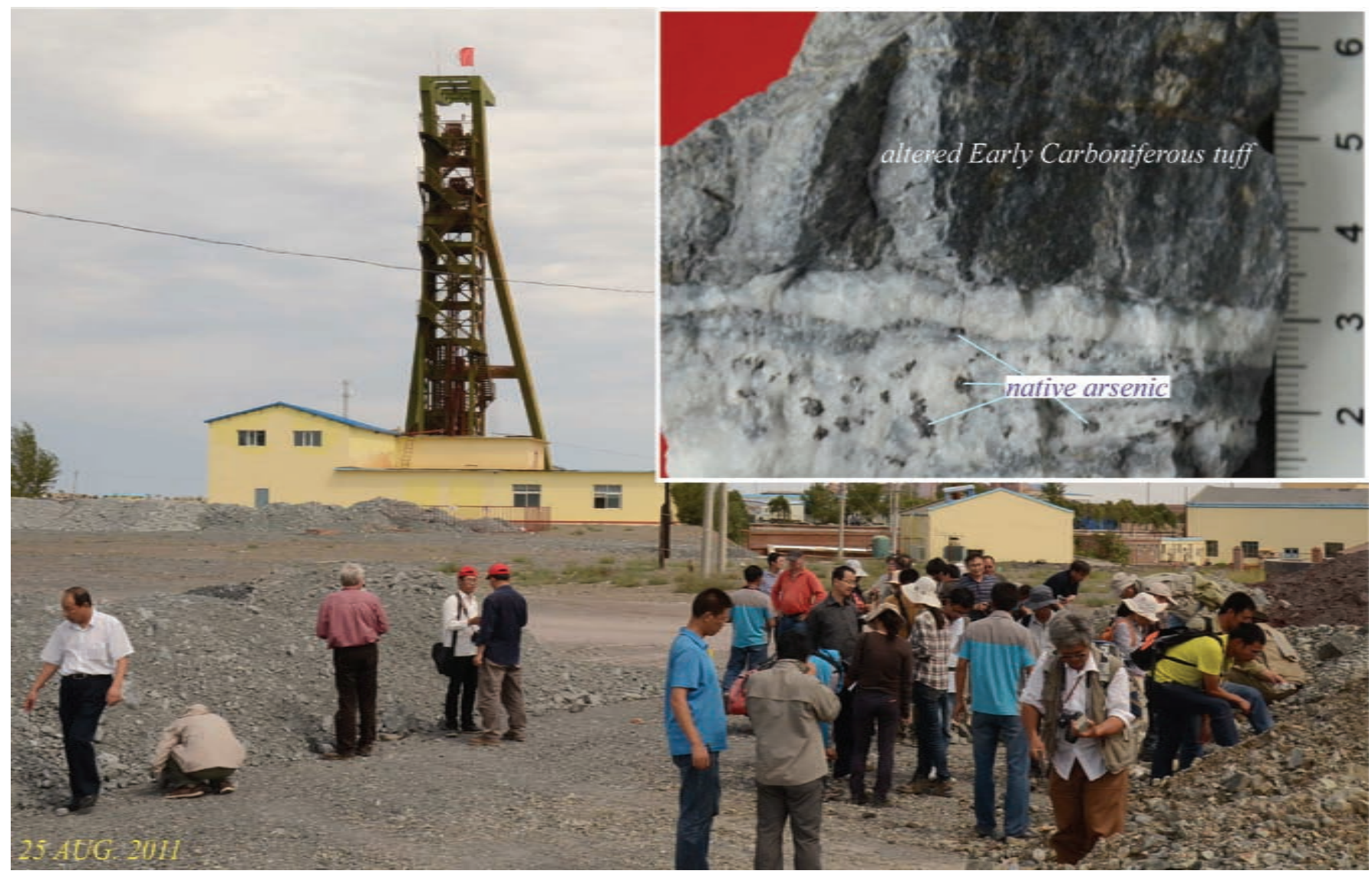

Figure 3. Participants of the field-trip are studying fresh ore from about $400 \mathrm{~m}$ depth at the stockpile of the Baogutu gold mine. Insert: native arsenic in quartz vein cutting altered Early Carboniferous volcaniclastic rock. 
mineralization in the eastern section of the Alatao Range. Ping Shen (Chinese Academy of Science, Beijing) described the minerlization characteristics of the Baogutu porphyry $\mathrm{Cu}$ deposits. Fang An (Peking University) reported the $\mathrm{Au}-\mathrm{Sb}-\mathrm{As}-\mathrm{Bi}$ assemblage in the Baogutu gold deposit and discussed their significance.

Bernd Lehmann (Technical University of Clausthal, Germany) summarized the Paleozoic accretionary orogenic evolution and related ore formation in Central Kazakhstan. Neodymium isotope data on calcalkaline and alkaline felsic intrusive rocks from the Ordovician island-arc evolution through to Permian postorogenic rifting display positive epsilon $\mathrm{Nd}$ values and indicate a mostly young continental lithosphere for Central Kazakhstan with minor old continental fragments such as the Kokchetav Massif with xenocrystic zircons up to 3.9 Ga old (SHRIMP data from Kröner et al., 2008). Anatoly Kurchavov (IGEM, Moscow) provided an overview of the magmatic-tectonic position of the Late Paleozoic copper ore deposits in Central Kazakhstan.

A special issue of Acta Petrologica Sinica, with about thirty papers describing the most recent progress and new results in regional geology, metallogenesis and exploration models, is prepared for publication in 2012. These papers will undoubtedly promote the understanding of the geological evolution and will be of benefit for the mineral resource exploration in the Balkash-western Junggar copper-gold province. The next workshop is scheduled to be held in the summer of 2013.

Acknowledgement: International S\&T Cooperation Program of China (Grant No. 2010DFB23390) and the NSFC (Grant No. 41110304039) provided financial support.

\section{References}

An, F., and Zhu, Y.-F., 2009. Significance of native arsenic in the Baogutu gold deposit, western Junggar, Xinjiang, NW China. Chinese Science Bulletin, 54: 1744-1749.

An, F., and Zhu, Y.-F., 2010. Native antimony in the Baogutu gold deposit (west Junggar, NW China): Its occurrence and origin. Ore Geology Reviews, 37: 214223.

Chen, B., and Zhu, Y.-F., 2011. Petrology, geochemistry and zircon U-Pb chronology of gabbro in Darbut ophiolitic melange, Xinjiang. Acta Petrologica Sinica, 27(6): 1746-1758 (in Chinese with English abstract).

He, G.Q., Chen, S.D., Xu, X., Li, J.Y., and Hao, J., 2004. An introduction to the explanatory text of the map of tectonics of Xinjiang and its neighboring area (1:250000, in Chinese with English abstract): Beijing, Geological Publishing House.

He, G.Q., Liu, J.B., Zhang, Y.Q., and Xu, X., 2007. Karamay ophioliic mélange formed during Early Paleozoic in western Junggar basin. Acta Petrologica Sinica, 23: 1573-1576 (in Chinese with English abstract).

Heinhorst, J., Lehmann, B., Ermolov, P., Serykh, V., and Zhurutin, S., 2000. Paleozoic crustal growth and metallogeny of Central Asia: evidence from magmatichydrothermal ore systems of Central Kazakhstan. Tectonophysics, 328: 69-87.

Kröner, A., Hegner, E., Lehmann, B., Heinhorst, J., Wingate, M.T.D., Liu, D.Y., and Ermelov, P., 2008. Palaeozoic arc magmatism in the Central Asian Orogenic Belt of Kazakhstan: SHRIMP zircon ages and whole-rock Nd isotopic systematics. Journal of Asian Earth Sciences, 32: 118130.

Kurchavov, A.M., Grankin, M.S., Malchenko, E.G., Khamzin, B.S., and Zhukovskii, V.I., 2002. Metallogenic zonality of the Devonian volcanoplutonic belt in Central Kazakhstan. Geology of Ore Deposits, 44: 18-25 (in Russia).
Windley, B.F., Alexeiev, D., and Xiao, W.J., 2007. Tectonic models for accretion of the Central Asian Orogenic Belt. Journal of the Geological Society of London, 164: 31-47.

Yakubuchuk, A., 2004. Architecture and mineral deposit settings of the Altaid orogenic collage: a revised model. Journal of Asian Earth Sciences, 23: 761779.

Zhu, Y.-F., and Ogasawara, Y., 2002. Carbon recycled into the deep Earth: Evidenced by dolomite dissociation in subductionzone rocks. Geology, 30: 947-950.

Zhu, Y.-F., and Xu, X., 2006. The discovery of Early Ordovician ophiolite mélange in Taerbahatai Mts., Xinjiang, NW China. Acta Petrologica Sinica, 22(12): 28332842 (in Chinese with English Abstract).

Zhu, Y.-F., Xu, X., Chen, B., and Xue, X.-Y., 2008. Dolomite marble and garnet amphibolite in the ophiolitic mélange in western Junggar: Relics of the Early Paleozoic oceanic crust and its deep subduction. Acta Petrologica Sinica, 24: 2767-2777 (in Chinese with English abstract).

\section{Yongfeng $\mathbf{Z h u}$}

School of Earth and Space Sciences, Peking University, Beijing 100871,

China

Email:yfzhu@pku.edu.cn

\section{Qinming Yan}

National 305 Project Office, Urumqi 830000, China

\section{Huadong Ma}

Xinjiang Resource and Environment

Research Center,

Urumqi 830000, China

\section{Bernd Lehmann}

Mineral Resources, Technical University

of Clausthal

Clausthal-Zellerfeld, 38678,

Germany 